Journal of Fish Biology 65, 1096-1107

Please email chris.carter@utas.edu.au for pdf

\section{Changes to feeding and dominance ranks following the introduction of novel feeds to African catfish}

\author{
C.G. CARTER* AND S.J. DAVIES ${ }^{\dagger}$ \\ *School of Aquaculture, University of Tasmania, Locked Bag 1-370, Launceston, \\ Tasmania 7250, Australia \\ †Department of Biological Sciences, University of Plymouth, Drake Circus, \\ Plymouth PL4 8AA, U. K.
}

(Received 25 September 2003, Accepted 13 July 2004)

Chris Carter: +61 3 63243823; fax +613 63243805; chris.carter@utas.edu.au 
The experiment aimed to examine the effect of changing feeds on individual feed intake and feeding and dominance ranks in groups of African catfish. Following feeding on a commercial feed (Com.) groups $(\mathrm{n}=3)$ of 6 catfish were either fed fish meal (FM42) or maize gluten (MG35) based feeds for 5 days before being switched to the other feed for 5 days. Energy intake was significantly lower on FM42 than on MG35, dry matter intake and protein intake were significantly lower on FM42 than on Com. and this occurred whether FM42 was fed first or second. There were no significant differences between intake of MG35 and Com. Thus, the action of changing the feed on its own did not affect feed intake since the decrease was shown to be feed-specific to FM42. Six types of agonistic behaviours were identified and used to assign dominance rank, there were no correlations between dominance and feeding ranks. This was due to non-linear hierarchies with one dominant fish in each group. Feeding ranks were more stable when feeding MG35 than FM42. Feeding rank stability (Kendall's coefficient of concordance) was significant in 5 out of 6 groups fed MG35 (compared with 3 out of 6 fed FM42). Feeding rank stability was higher in 5 out of the 6 groups when they were fed MG35 than when the same group was fed FM42. The experiment provided evidence that the introduction of a novel feed can, but does not necessarily, alter feed intake and that feed can influence the stability of feeding ranks.

Key Words: Clarias gariepinus, feed intake; feed change; hierarchies; individuals; novel feeds

\section{INTRODUCTION}

Differences in patterns of feed intake between individual fish in groups is influenced by a variety of intrinsic and extrinsic factors such as the species of fish, genetic background, rank, experience, size, number of competitors and feed availability (Forrester, 1991; McCarthy et al., 1993; Carter et al., 2001; Sloman \& Armstrong, 2002). The presence of social hierarchies and their effects on feeding have been demonstrated in wild (Fausch, 1984; Forrester, 1991) and in cultured fish (McCarthy et al., 1992). The possibility of 
prey choice is a major difference between fish in the wild and those under culture where only one feed of one size and formulation is usually available at any one time. Thus, in the wild, one possible effect of social hierarchies and competition between individuals within a group is for high and low ranking fish to consume different diets (Forrester, 1991). When one nutritionally complete formulated feed is used the major effect of social hierarchies is an unequal distribution of the feed so that higher ranked individuals consume more and grow faster (McCarthy et al., 1992; Winberg et al., 1993) although this is not always the case (Sloman \& Armstrong, 2002).

A novel feed is a potential feed source, but it has to be tested by the consumer since it may have detrimental effects and therefore risks associated with its consumption. Animals are generally thought to exhibit an exploratory feeding strategy and will try out novel foods, but only in small amounts initially (Forbes, 1999). There is evidence that animals show flexibility in feeding strategies that incorporate individual variation in the relative importance of risks and benefits ("pay-offs") and therefore are sensitive to social rank (Bateson, 2002; Sloman \& Armstrong, 2002). However, the effect of introducing a novel feed on individual feed intake, particularly in relation to rank, has received considerably less attention in fish (Moutou et al., 1999). Information on the effects of introducing a novel feed formulation on individual feed intake in relation to group feeding is limited in fish. Replacing an established feed with a novel feed often results in changes to group feed intake in fish (Bromley \& Adkins, 1981; Bres, 1989; Refstie et al., 1998). Increases or decreases in feed intake may occur and be permanent or transient. Reasons for decreased feed intake may relate to meeting nutritional requirements (particularly energy) (de la Higuera, 2001), the presence of deleterious components (Perera et al., 1995; Refstie et al., 1998), unfamiliarity or neophobia (Forbes, 1999), in which case feed intake is likely to return to pre-change levels (Toften \& Jobling, 1997). When pea protein replaced fish meal in a salmon feed there was an initial decrease in group feed intake followed by a steady increase (Wybourne, 1997; Wybourne \& Carter, 1998). However, changes in individual feed intake and feeding hierarchy dynamics were more complex and showed short-term changes in feeding strategies that related to rank. When the novel feed was first fed the lower ranked fish increased their relative share of the eaten food and the higher ranked fish decreased theirs (Wybourne, 1997). The 
original pattern of feeding returned after 7 days. It was suggested that the lower ranked fish "risked" a higher intake of the novel feed because the potential benefit was greater to lower ranked than to higher ranked fish (Wybourne, 1997). Under most circumstances the benefit of increased feed intake is increased growth or a decreased chance of starvation (Symons, 1968; Fausch, 1984; Koebele, 1985; Jobling \& Baardvik, 1994).

The current experiment aimed to investigate the short-term effect of novel feeds on feed intake and to test the hypothesis that the introduction of a novel feed formulation would result in changes to the stability of feeding ranks and therefore to the relationship between dominance rank and feeding rank. African catfish (Clarias gariepinus Burchell) were selected for study because they are omnivorous and can be successfully fed a range of plant and animal based protein sources, they exhibit agonistic behaviours but are also amenable to culture in groups (Haylor, 1993). A low ration was used to promote the formation and maintenance of social and feeding hierarchies (McCarthy et al., 1992). The experiment was designed with two treatments in order to distinguish between the effect of changing a feed from feed-specific effects.

\section{FISH}

\section{MATERIALS AND METHODS} Sciences, University of Plymouth using African catfish spawned on-site and fed on commercial feeds (Baker \& Davies, 1996). Six fish per tank were randomly distributed into six 80-1 tanks in a freshwater recirculation system (Baker \& Davies, 1996). Temperature $\left(27.5 \pm 0.4^{\circ} \mathrm{C}\right)$ and photoperiod (12:12) were maintained throughout the experiment. Water was treated through physical and biofilters and water quality parameters (dissolved oxygen, $\mathrm{pH}$, ammonia, nitrate and nitrite) were monitored to ensure water quality remained well within limits for African catfish (Baker \& Davies, 1996). At the start of the experiment fish were anaesthetised $\left(0.01 \mathrm{ml} \mathrm{l}^{-1}, 2\right.$-phenoxyethanol), body mass measured and individually marked on the dorsal surface of the head by Panjet (Hart \& Pitcher, 1969). The experiment lasted for 19 days (9 days using a commercial feed followed by Period 1 (days 10-14) and Period 2 (days 15-19) when 
experimental feeds were used (see below). At the end of the experiment the fish were not fed for 24 hours and then anaesthetised, weighed and returned to stock. Intermediate weights were not measured to avoid disturbance to the fish prior to changing feeds. Specific growth rate $(G)$ was calculated as

$$
G\left(\% d^{-1}\right)=100 \times\left(\ln \left(M_{F} / M_{S}\right)\right) \times d^{-1}
$$

where $\mathrm{M}_{\mathrm{S}}$ and $\mathrm{M}_{\mathrm{F}}$ are the wet body mass ( $\mathrm{g}$ ) at the start and finish of the experiment, respectively, and $d$ the number of days (20). The intra-group variation in individual wet body mass was calculated as the coefficient of variation (CV) for wet body mass.

\section{FEEDS AND TREATMENTS}

Prior to the experiment and for the first nine days of the experiment the fish were fed a commercial trout feed (Trouw UK, Standard Expanded 40). Two experimental feeds were formulated to be isoenergetic and isonitrogenous, these were then fed for two consecutive periods of 5 days: Treatment 1, fed FM42 followed by MG35 to three groups (tanks); Treatment 2, fed MG35 followed by FM42 to three groups (tanks). The commercial feed contained typical ingredients including fish, cereal and oilseed products and by-products and the chemical composition is provided in Table I. The experimental catfish diets were made immediately prior to the experiment (Baker \& Davies, 1996). Feed FM42 contained low temperature (LT) fish meal as the main dietary protein. Feed MG35 contained maize gluten to replace $75 \%$ of the fish meal protein (Table I).

\section{FEED INTAKE}

A group meal equivalent to $0.5 \%$ total group initial body mass (\% BW) was supplied by hand once a day in the morning (1000-1100 h). The feed was dropped into the same part of the tank and fed at a rate that maintained 5 pellets in the tank until eaten, groups of fish were fed in this way for $10 \mathrm{~min}$ each day. This ensured food was offered in a spatially and temporally defensible way. Groups (tanks) were fed in random order. Feed intake by individual fish was measured every day (number of pellets eaten multiplied by average pellet mass for each diet) using a video camera mounted above the tank. This 
position allowed successful identification of each individual from the Panjet marks on the broad dorsal surface of the head. Share of the group meal was calculated from the individual feed intake on each day as a percentage of the feed eaten by the group so that

Share of group meal $\left(\mathrm{m}_{\mathrm{j}}, \%\right)=100 \mathrm{~F}_{\mathrm{j}} / \mathrm{F}_{\mathrm{jg}}$

(McCarthy et al., 1999) where $m_{j}(j=1$ to 5 ) is the share of group meal for each fish for days 1 to $5, F_{j}$ was the feed intake of an individual and $F_{j g}$ the total group feed intake for each of those days. The share of group meal for five days was averaged to calculate a mean share of group meal for each feeding period (initial period, $\mathrm{M}_{\mathrm{i}}$; Period 1, $\mathrm{M}_{1}$; Period $\left.2, \mathrm{M}_{2}\right)$ and over the entire experiment $\left(\mathrm{M}_{\mathrm{x}}\right)$. The mean share of meal was used to assign a feeding rank to each fish.

\section{ANALYSIS OF BEHAVIOUR}

Agonistic behaviour was measured on 6 days, 2 to 3 hours after feeding, for 10 min using the video camera as described above: two days during the initial period (days 7,9); 2 days (days 11,13) during Period 1; 2 days (days 16,18) during Period 2. In defining agonistic behaviours of catfish a previous study on channel catfish (Ictalurus punctatus Rafinesque) was referred to (Wilson \& Roys, 1994). These agonistic behaviours were adapted for the present study: change direction (rapidly towards another fish), follow, chase, displace ("push thrust", "tail thrust" and "push"), head to head, and bite ("bite" and "nip") (Wilson \& Roys, 1994). The loser would either flee or be displaced from its original position. The winner and loser were recorded for each distinct encounter (a group of one or more behaviours separated by no activity). To assign each fish a dominance rank a dominance index (D) was calculated as

$$
\mathrm{D}=\mathrm{A}_{\mathrm{v}} / \mathrm{A}_{\mathrm{v}+\mathrm{d}}
$$

(Winberg et al., 1991; McCarthy et al., 1999) where $\mathrm{A}_{\mathrm{v}+\mathrm{d}}$ was the total number of agonistic interactions that a fish was involved in (victories plus defeats) and $A_{V}$ the number in which the fish was the victor. An average dominance index was calculated for 
172 each feeding period (initial period, $\mathrm{D}_{\mathrm{i}}$; Period $1, \mathrm{D}_{1}$; Period 2, $\mathrm{D}_{2}$ ) and over the entire experiment $\left(D_{X}\right)$. In a few cases where there were no recorded behaviours, and $D$ could not be calculated, the fish were ranked below fish for which $\mathrm{v}>\mathrm{d}$ and above fish where $\mathrm{v}$ $<\mathrm{d}$.

\section{STATISTICAL ANALYSIS}

Means are presented \pm S.E.M. Coefficients of variation were calculated as CV $(\%)=100$ (s.d. / mean). Percentage data were arcsine transformed prior to analysis (nontransformed data are presented). Two-way analysis of variance was used to compare the effects of treatment (order of feeds) and feeds. Where there was a significant different a Tukey-Kramer multiple comparison was used. Kendall's coefficient of concordance was used to examine the stability of individual feeding (M) and dominance (D) ranks of fish in groups between all the days on which measurements were made within each period and over the entire experiment (Sokal \& Rohlf, 1995; McCarthy et al., 1999). Correlation analysis was by Spearman rank correlation, the size of the correlation coefficient and level of significance ( $\mathrm{P}$ value) were used to indicate the relative strength of correlations.

\section{GROWTH}

There were no significant differences in the initial mean group body mass or in the growth of the catfish on the two treatments (Table II). The distribution of body mass within each group was calculated by the coefficient of variation (CV) for body mass (Table II), there were no significant differences (2-way ANOVA) due to treatment or between the initial and final $\mathrm{CV}$ values.

\section{GROUP FEED INTAKE}

Feed intake, as dry matter, crude protein and energy, was analysed in relation to the order of feed (treatment) and feed, treatment had no effect but there was a significant difference between feeds with no interaction effect (Table II). Consequently, feed intake data were pooled by feed for multiple-comparison. Dry matter intake was significantly lower for the fish meal based feed (FM42) compared to the commercial feed (Com.), 
there was no differences between the maize gluten (MG35) feed and either of the other feeds: mean feed intakes for FM42, MG35 and Com. were 3.66, 4.23 and $4.69 \mathrm{mg} \mathrm{g}^{-1} \mathrm{~d}^{-1}$, respectively $(\mathrm{F}=10.18, \mathrm{P}=0.002)$. Similarly, crude protein intake was significantly lower for FM42 compared to Com., there were no differences between MG35 and either of the other feeds: mean feed intakes for FM42, MG35 and Com. of 1.43, 1.54 and 1.71 mg protein $\mathrm{g}^{-1} \mathrm{~d}^{-1}$, respectively $(\mathrm{F}=5.66, \mathrm{P}=0.015)$. However, gross energy intake was significantly lower for FM42 compared to MG35, there was no difference between Com. and either of the other feeds: mean energy intakes for FM42, Com. and MG35 of 71.44, 78.46 and $84.01 \mathrm{~J} \mathrm{~g}^{-1} \mathrm{~d}^{-1}$, respectively $(\mathrm{F}=5.00, \mathrm{P}=0.021)$. Thus, the action of changing the feed did not necessarily affect feed intake and the response was shown to be feedspecific.

\section{INDIVIDUAL FEEDING RANKS}

The stability of a groups feeding hierarchy was shown by the magnitude and significance of Kendall's coefficient of concordance, this showed the level of concordance between feeding ranks of all individuals in a group over the 5 days of each period (Table IV). All groups were fed the same feed during the initial period and Kendall's coefficient was significant for all groups. Feeding ranks, therefore, showed stability over the initial period although there were differences in the strength between groups. Changing the feed did not show an unequivocal effect on the stability of feeding ranks due to the feed or treatment. However, feeding ranks were more stable when feeding MG35 $\left(\mathrm{M}_{2}\right.$, Treatment 1; $\mathrm{M}_{1}$, Treatment 2) than FM42 (Table IV). When MG35 was fed significant concordance was found in 5 out of 6 groups (83\%) compared with 3 out of 6 groups when FM42 was fed. In addition, concordance was higher feeding MG35 than feeding FM42 in 5 of the 6 groups.

\section{BEHAVIOURAL INTERACTIONS}

Six types of behaviours were identified. There were no significant differences (2way ANOVA) in the percentage occurrence between treatment or feed so the data were pooled. Follow (28.5\% of total behaviours observed), chase $(22.6 \%)$, displace $(19.2 \%)$ 
and bite $(16.3 \%)$ were the most frequently observed behaviours where as change $(8.8 \%)$ and the head to head position $(4.6 \%)$ were observed less frequently.

Dominance ranks within the groups were not stable since there were no significant values of Kendall's coefficient of concordance for any of the groups within the three periods and only one calculated over the entire time (Table V). Consequently, none of the 18 possible correlations (three periods for six tanks) between dominance rank and feeding rank were significant. The most likely explanation for this was that each group had one dominant fish and the other fish were not part of a linear hierarchy. The fish with the highest dominance rank also had the highest feeding rank in four groups, the second highest in one group and was ranked fourth in the remaining group. In contrast, the fish with the lowest dominance rank had more variable feeding ranks $(2,3,3,5,6)$ and in the remaining group three fish had an equal lowest dominance rank.

\section{DISCUSSION}

The presence and absence of stable dominance hierarchies is partly species specific and partly context specific. In the present experiment dominance rank was not stable and was explained by groups having a non-linear hierarchy structure with one dominant individual and the other fish having variable dominance ranks. The cichlid Tilapia rendalli Boulenger showed high dominance rank stability that was not shown by other Tilapia species (McCarthy et al., 1999). Flatfish generally show few agonistic behaviours and no dominance ranking was demonstrated in a flatfish Rhombosolea tapirina Günther (Shelverton \& Carter, 1998) where as dominance ranking in salmonids is well documented. Environment is important and agonistic behaviours are often exhibited by fish held in tanks. In these cases, the occurrence and intensity of agonistic behaviours is heavily influenced by extrinsic factors such as the defensibility of primary resources such as space and food, group size and potential competitors as well as intrinsic characteristics such as size, experience, hunger or motivation (Koebele, 1985; McCarthy et al., 1993; Carter et al., 1994; Pettersson et al., 1996; Cutts et al., 2002). In the present experiment, African catfish showed many of the behaviours shown by channel catfish but the intensity was lower (Wilson \& Roys, 1994). This could have been due to species 
differences, larger group size of African catfish or the catfish being in an established hierarchy and showing less overt aggression.

The present experiment demonstrated that the introduction of a novel feed can, but does not necessarily, alter group feed intake. The experimental design showed that the response was feed-specific and not just an effect of changing the feed. The experimental feeds were formulated to be of similar nutrient composition so that only the inclusion of different ingredients was being compared. The lower feed intake of FM42 was unlikely to have been caused by fish being satiated because the supplied rations were low and below maximum ration or predicted maximum energy intake (Hossain et al., 1998). It is more likely that appetite was suppressed either by one or more dietary components or by a different balance of dietary components in the FM42 feed (de la Higuera, 2001). Both feeds contained the same fish meal but inclusion in FM42 was over four times higher than inclusion in MG35. The commercial feed contained cereal grain products and by-products so that MG35 was more similar than FM42 in ingredient composition to the commercial feed. The greater similarity between the commercial feed, the regular feed, and MG35 may have explained the difference in response to MG35 and FM42 on first exposure. Thus, relatively small differences in composition probably led to decreased intake of FM42 due to neophobia (Forbes, 1999). Of added interest were indicators that African catfish exhibited feed-specific changes to feeding hierarchy stability.

Although the effects of changing feeds on feeding rank stability were not unequivocal, due to one group, the data provided evidence of feed-specific effects on feeding rank stability. Feeding rank dynamics were different in this group (tank 5) compared to the other groups, feeding rank stability over the initial period was the lowest (Kendall's coefficient of 11.45 and only marginally significant, $X_{0.05}^{2}=11.07$ ) and feeding rank stability the most variable over the experiment (Table IV). Feeding rank stability was highest during the initial period of feeding when the commercial feed was fed to all groups. The commercial feed was used prior to the experiment and the fish were acclimated to this feed, they had learnt to associate the feed with metabolic consequences of eating it (Forbes \& Shariatmadari, 1996). The analysis of feeding rank stability during the initial period was, therefore, considered to reflect experimental conditions other than 
feed effects. Following the introduction of the novel feeds, feeding rank stability decreased (Period 1 compared with the initial period and Period 2) and was lower for one feed than the other. The decrease during Period 1 showed the introduction of a novel feed had an effect on the feeding hierarchy irrespective of whether there was a decrease in group feed intake or not. Five out of six groups had higher feeding rank stability on the MG35 feed, irrespective of the order in which the two feeds were presented.

In the present experiment the feed-specific effects on feeding hierarchy stability may relate to the balance between potential risks and benefits associated with consuming a novel feed. Jackdaws (Corvus monedulla L.) of different social rank showed different strategies in response to novel feeds, dominant individuals were less exploratory and were never the first to try a novel feed (Katzir, 1983). There is some evidence to suggest that birds are sensitive to feed preferences of other individuals and may regulate their feed selection accordingly (Sherwin et al., 2002). It is not clear whether fish have the ability to respond in this way or whether increasing hunger stimulated increased feeding by individuals that had decreased their feed intake in response to the novel feed. Return to feeding by individual Atlantic salmon held in dominant-subordinate pairs, that had been exposed to a predator (model), was dependent on their level of hunger not their dominance rank (Gotceitas \& Godin, 1991). In the present experiment feed-specific differences were relatively subtle and probably reflected the small differences between the feeds.

The authors would like to thank A-W.A. Abdel-Warith for help in making the feeds.

Baker, R. T. M. \& Davies, S. J. (1996). Changes in tissue a-tocopherol status and degree of lipid peroxidation with varying $\alpha$-tocopherol acetate inclusion in diets for the African catfish. Aquaculture Nutrition 2, 71-79.

Bateson, M. (2002). Recent advances in our understanding of risk-sensitive foraging preferences. Proceedings of the Nutrition Society 61, 509-516.

Brafield, A. E. (1985). Laboratory studies of energy budgets. In Fish Energetics New Perspectives, (Tytler, P. \& Calow, P. eds), pp. 257-281. London \& Sydney: Croom Helm. 
Bres, M. (1989). The effects of prey relative abundance and chemical cues on prey selection in rainbow trout. Journal of Fish Biology 35, 439-445.

Bromley, P. J. \& Adkins, T. C. (1981). The influence of cellulose filler on feeding, growth and utilization of protein and energy in rainbow trout (Salmo gairdneri Richarson). Journal of Fish Biology 24, 235-244.

Carter, C., Houlihan, D., Keissling, A., Medale, F. \& Jobling, M. (2001). Physiological effects of feeding. In Food Intake in Fish, (Houlihan, D., Boujard, T. \& Jobling, M. eds), pp. 297-331. Oxford: Blackwell Science.

Carter, C. G., McCarthy, I. D., Houlihan, D. F., Johnstone, R., Walsingham, M. V. \& Mitchell, A. I. (1994). Food consumption, feeding behaviour and growth of triploid and diploid Atlantic salmon, Salmo salar L., parr. Canadian Journal of Zoology 72, 609617.

Cutts, C. J., Metcalfe, N. B. \& Taylor, A. C. (2002). Fish may fight rather than feed in a novel environment: metabolic rate and feeding motivation in juvenile Atlantic salmon. Journal of Fish Biology 60, in press.

de la Higuera, M. (2001). Effects of nutritional factors and feed characteristics on feed intake. In Food Intake in Fish, (Houlihan, D., Boujard, T. \& Jobling, M. eds), pp. 250268. Oxford: Blackwell Science.

Fausch, K. D. (1984). Profitable stream positions for salmonids: relating specific growth rate to net energy gain. Canadian Journal of Zoology 62, 441-451.

Forbes, J. M. (1999). Natural feeding behaviour and feed selection. In Regulation of Feed Intake, (Heide, v. d. D., Huisman, E. A., Kanis, E., Osse, J. W. M. \& Verstegen, M. W. A. eds), pp. 3-12. Wallingford, Oxon: CABI Publishing.

Forbes, J. M. \& Shariatmadari, F. (1996). Short-term effects of food protein content on subsequent diet selection by chickens and the consequences of alternate feeding of high- and low-protein foods. British Poultry Science 37, 597-607.

Forrester, G. E. (1991). Social rank, individual size and group composition as determinants of food consumption by humbug damselfish, Dascyllus aruanus. Animal Behaviour 42, 701-711.

Gotceitas, V. \& Godin, J.-G. J. (1991). Foraging under the risk of predation in juvenile Atlantic salmon (Salmo salar L.): effect of social status and hunger. Behavioral Ecology and Sociobiology 29, 255-261.

Hart, P. J. B. \& Pitcher, T. J. (1969). Field trials of fish marking using a jet inoculator. Journal of Fish Biology 1, 383-385.

Haylor, G. S. (1993). Aspects of the biology and culture of the African catfish Clarias gariepinus (Burchell 1822) with particular reference to developing African countries. In Recent Advances in Aquaculture Vol. 4., (Muir, J.F. \& Roberts, R.J.), pp. 233-294. Oxford: Blackwell Science

Hossain, M. A. R., Haylor, G. S. \& Beveridge, M. C. M. (1998). Quantitative estimation of maximum daily intake of African catfish, Clarius gariepinus Burchell, fingerlings using radiography. Aquaculture Nutrition 4, 175-182.

Jobling, M. \& Baardvik, B. M. (1994). The influence of environmental manipulations on inter- and intra- individual variation in food acquisition and growth performance of Arctic charr, Salvelinus alpinus. Journal of Fish Biology 44, 1069-1087. 
Katzir, G. (1983). Relationships between social structure and response to novelty in captive jackdaws, Corvus monedula L. II. Response to novel palatable food. Behaviour 87, 183-200.

Koebele, B. R. (1985). Growth and the size hierarchy effect: an experimental assessment of three proposed mechanisms; activity differences, disproportional food aquisition, physiological stress. Environmental Biology of Fishes 12, 181-188.

McCarthy, I. D., Carter, C. G. \& Houlihan, D. F. (1992). The effect of feeding hierarchy on individual variability in daily feeding of rainbow trout, Oncorhynchus mykiss (Walbaum). Journal of Fish Biology 41, 257-263.

McCarthy, I. D., Gair, D. J. \& Houlihan, D. F. (1999). Feeding rank and dominance in Tilpaia rendalli under defensible and indefensible patterns of food distributions. Journal of Fish Biology 55, 854-867.

McCarthy, I. D., Houlihan, D. F., Carter, C. G. \& Moutou, K. (1993). Variation in individual food consumption rates of fish and its implications for the study of fish nutrition and physiology. Proceedings of the Nutrition Society 52, 411-420.

Moutou, K. A., McCarthy, I. D. \& Houlihan, D. F. (1999). The effect of dietary flumequine on food consumption and growth in rainbow trout. Aquaculture International 9, 95-102.

Perera, W. M. K., Carter, C. G. \& Houlihan, D. F. (1995). Feed consumption, growth and growth efficiency of rainbow trout, Oncorhynchus mykiss (Walbaum), fed diets containing bacterial single cell protein. British Journal of Nutrition 73, 591-603.

Pettersson, J., Johnsson, J. I. \& Bohlin, T. (1996). The competitive mechanism of large body size declines with increasing group size in rainbow trout. Journal of Fish Biology 49, 370-372.

Refstie, S., Storebakken, T. \& Roem, A. J. (1998). Feed consumption and conversion in Atlantic salmon (Salmo salar) fed diets with fish meal, extracted soybean meal or soybean meal with reduced content of oligosaccharides, trypsin inhibitors, lectins and soya antigens. Aquaculture 162, 301-312.

Shelverton, P. A. \& Carter, C. G. (1998). The effect of ration on behaviour, food consumption and growth in juvenile greenback flounder (Rhombosolea tapirina: Teleostei). Journal of the Marine Biological Association of the United Kingdom 78, 1307-1320.

Sherwin, C. M., Heyes, C. M. \& Nicol, C. J. (2002). Social learning influences the preferences of domestic hens for novel food. Animal Behaviour 63, 933-942.

Sloman, K. A. \& Armstrong, J. D. (2002). Physiological effects of dominance hierachies: laboratory artefacts or natural phenomena? Journal of Fish Biology 61, 1-23.

Sokal, R. R. \& Rohlf, F. J. (1995). Biometry Third Edition. New York:W.H.Freeman and Company.

Symons, P. E. K. (1968). Increase in aggression and in strength of the social hierarchy among juvenile Atlantic salmon deprived of food. Journal of the Fisheries Research Board of Canada 25, 2387-2401.

Toften, H. \& Jobling, M. (1997). Feed intake and growth of Atlantic salmon, Salmo salar L., fed diets supplemented with oxytetracycline and squid extract. Aquaculture Nutrition 3, 145-151.

Wilson, J. L. \& Roys, L. L. (1994). Behavioural interactions in juvenile channel catfish Ictalurus punctatus. Journal of Applied Aquaculture 3, 363-381. 
418 Winberg, S., Carter, C. G., McCarthy, I. D., He, Z.-Y., Nilsson, G. E. \& Houlihan, D. F. 419 (1993). Feeding rank and brain serotonergic activity in rainbow trout Oncorhynchus $420 \quad$ mykiss. Journal of Experimental Biology 179, 197-211.

421 Winberg, S., Nilsson, G. E. \& Olsen, K. J. (1991). Social rank and brain levels of 422 monoamines and monoamine metabolites in Arctic charr, Salvelinus arcticus (L.). 423 Journal of Comparative Physiology 168A, 241-246.

424 Wybourne, B. A. (1997). Adaptation to novel diets by Atlantic salmon (Salmo salar L.). 425 Honours Thesis. University of Tasmania, 
Table I. Ingredient and chemical composition of experimental (FM42, MG35) and commercial (Com.) feeds

\begin{tabular}{|c|c|c|c|}
\hline \multicolumn{4}{|c|}{ Feed } \\
\hline & FM42 & MG35 & Com. \\
\hline \multicolumn{4}{|l|}{$\begin{array}{l}\text { Ingredient composition } \\
\left(\mathrm{g} \cdot \mathrm{kg}^{-1}\right)\end{array}$} \\
\hline Low temperature fish meal & 420 & 100 & \\
\hline Maize gluten & & 350 & \\
\hline Wheat meal & 350 & 320 & \\
\hline Blood meal & 20 & 20 & \\
\hline Cod liver oil & 44 & 47 & \\
\hline Corn oil & 44 & 57 & \\
\hline$\alpha$-Cellulose & 67 & 62 & \\
\hline $\mathrm{CMC}$ & 20 & 20 & \\
\hline Vitamin premix 1 & 20 & 20 & \\
\hline Mineral premix ${ }^{2}$ & 10 & 10 & \\
\hline Chromic oxide & 10 & 10 & \\
\hline \multicolumn{4}{|l|}{ 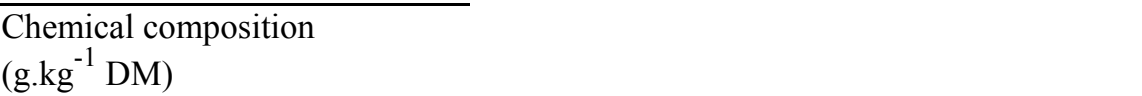 } \\
\hline Dry matter $\left(\mathrm{g} \cdot \mathrm{kg}^{-1}\right)$ & 948 & 942 & 910 \\
\hline Crude protein & 411 & 386 & 400 \\
\hline Crude fat & 121 & 127 & 80 \\
\hline $\mathrm{NFE}^{3}$ & 380 & 431 & 350 \\
\hline Ash & 88 & 56 & 80 \\
\hline Gross energy (MJ.kg $\left.{ }^{-1} \mathrm{DM}\right)$ & 20.6 & 21.1 & 18.4 \\
\hline
\end{tabular}

${ }^{1}$ Vitamin premix (provides / kg Feed DM): Vitamin A, 1600 IU; Vitamin D, 2400 IU; Vitamin E, 160 mg; Vitamin K, 16 mg; Thiamin, 36mg; Riboflavin,48mg; Pyridoxine, 24mg; Niacin, $288 \mathrm{mg}$; Pantothenic acid, 96mg; Folic acid, $8 \mathrm{mg}$; Biotin, $1.3 \mathrm{mg}$; Cyanocobalamin, $48 \mu \mathrm{g}$; Ascorbic acid, $720 \mathrm{mg}$; Choline chloride, 320mg.

${ }^{2}$ Mineral premix (provides / kg Feed DM): Calcium orthophosphate, 1.6 g; Calcium carbonate, 4g; Ferrous sulphate, 1.5g; Potassium phosphate, 2.8g; Sodium phosphate, 1g; Aluminium sulphate, $0.02 \mathrm{~g}$; Zinc sulphate, $0.24 \mathrm{~g}$; Copper sulphate, $0.20 \mathrm{~g}$; Manganese sulphate, $0.08 \mathrm{~g}$; Potassium iodide $0.02 \mathrm{~g}$.

${ }^{3}$ NFE calculated as dry matter - (crude protein + crude lipid + ash $)$

${ }^{4}$ Calculated from nutrient energy values for crude protein $\left(23.6 \mathrm{MJ} \mathrm{kg}^{-1}\right)$, crude lipid (36.2 $\mathrm{MJ} \mathrm{kg}^{-1}$ ) and carbohydrate (17.2 $\mathrm{MJ} \mathrm{kg}^{-1}$ ) (Brafield, 1985) 
451 Table II. Body mass, growth and coefficient of variation for body mass

452 of African catfish on two feeding treatments (Mean \pm SEM, $n=3$ )

453

\begin{tabular}{llll}
\hline Treatment & Treatment 1 & Treatment 2 & $\mathrm{P}$ \\
\hline
\end{tabular}

$\begin{array}{llll}\text { Initial body mass }(\mathrm{g}) & 195.8 \pm 4.5 & 200.1 \pm 7.9 & \mathrm{~ns}\end{array}$

$\begin{array}{llll}\text { Final body mass }(\mathrm{g}) & 213.7 \pm 3.6 & 212.6 \pm 6.8 \quad \mathrm{~ns}\end{array}$

Change in body mass $(\mathrm{g}) \quad 17.9 \pm 1.4 \quad 12.5 \pm 1.6 \quad$ ns

$\mathrm{G}\left(\% \mathrm{~d}^{-1}\right) \quad 0.63 \pm 0.06 \quad 0.44 \pm 0.07 \quad$ ns

CV initial body mass (\%) $\quad 15.7 \pm 0.8 \quad 16.2 \pm 1.4 \quad$ ns

CV final body mass $(\%) \quad 18.7 \pm 1.4 \quad 14.1 \pm 1.5 \quad$ ns

454 Treatment 1: FM42 followed by MG35

455 Treatment 2: MG35 followed by FM42 
Table III. Feed intake of dry material (DM), crude protein (CP) and gross energy (GE) of African catfish on two feeding treatments (Mean \pm SEM, $n=3$ )

\begin{tabular}{llllccc}
\hline Feed intake & Feed & Treatment 1 & Feed & Treatment 2 & 2 way & Anova \\
\cline { 5 - 7 } & & & & & & \\
DM: mg g $^{-1} \mathrm{~d}^{-1}$ & & & & & & \\
Period initial & Com & $4.97 \pm 0.04$ & Com & $4.40 \pm 0.47$ & Treatment & $\mathrm{ns}$ \\
Period 1 & FM42 & $3.56 \pm 0.21$ & WG32 & $4.33 \pm 0.11$ & Feed & $<0.05$ \\
Period 2 & WG32 & $4.12 \pm 0.09$ & FM42 & $3.75 \pm 0.05$ & Interaction & $\mathrm{ns}$
\end{tabular}

CP:

mg protein $\mathrm{g}^{-1} \mathrm{~d}^{-1}$

Period initial

$\begin{array}{lclccc}\text { Com } & 1.81 \pm 0.01 & \text { Com } & 1.60 \pm 0.17 & \text { Treatment } & \text { ns } \\ \text { FM42 } & 1.39 \pm 0.08 & \text { WG32 } & 1.57 \pm 0.04 & \text { Feed } & <0.05 \\ \text { WG32 } & 1.50 \pm 0.03 & \text { FM42 } & 1.46 \pm 0.02 & \text { Interaction } & \text { ns }\end{array}$

Period 1

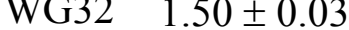

FM42 $1.46 \pm 0.02$

Interaction

GE: $\mathrm{J} \mathrm{g}^{-1} \mathrm{~d}^{-1}$

Period initial

Period 1

Com $\quad 83 \pm 0.7$

Com $74 \pm 7.8$

FM42 $70 \pm 4.1$

WG32 $86 \pm 2.2$

Treatment ns

Period 2

WG32 $82 \pm 1.8$

FM42 $73 \pm 0.9$

Feed $<0.05$

Interaction ns

Treatment 1: FM42 followed by MG35

460 Treatment 2: MG35 followed by FM42

461 
462 Table IV. Analysis of stability in individual feeding ranks in three 463 feeding periods $\left(\mathrm{M}_{\mathrm{i}}, \mathrm{M}_{1}, \mathrm{M}_{2}\right)$ and over the entire experiment $\left(\mathrm{M}_{\mathrm{x}}\right)$ for 464 African catfish in six groups on two feed treatments. Data presented 465 as Kendall's coefficient of concordance (corrected for ties) using $\chi^{2}$ 466 statistic.

467

\begin{tabular}{lllll}
\hline Group & Feeding & Period & & \\
\cline { 2 - 5 } & $\mathrm{M}_{\mathrm{i}}$ & $\mathrm{M}_{1}$ & $\mathrm{M}_{2}$ & $\mathrm{M}_{\mathrm{x}}$ \\
\hline
\end{tabular}

Treatment 1

Feed Com. FM42 MG35

$\begin{array}{lllll}1 & 18.08^{* *} & 14.31^{*} & 18.43^{* *} & 51.02 * * * \\ 4 & 15.31^{*} & 13.54^{*} & 13.60^{*} & 30.91 * * * \\ 6 & 17.88^{* *} & 6.71 & 11.57^{*} & 28.92 * * *\end{array}$

Treatment 2

Feed

Com. MG35 FM42

$\begin{array}{lllll}2 & 14.74 * & 17.11 * * & 11.02 & 28.90 * * * \\ 3 & 20.57^{* * *} & 16.71 * * & 7.62 & 34.30^{* * *} \\ 5 & 11.45^{*} & 1.42 & 19.91 * * * & 12.79 *\end{array}$


469 Table V. Analysis of stability in individual dominance ranks in three 470 feeding periods $\left(D_{i}, D_{1}, D_{2}\right)$ and over the entire experiment $\left(D_{x}\right)$ for 471 African catfish in six groups on two feed treatments. Data presented 472 as Kendall's coefficient of concordance (corrected for ties) using $\chi^{2}$ 473 statistic.

474

\begin{tabular}{lllll}
\hline Group & Feeding & Period & & \\
\cline { 2 - 5 } & $\mathrm{D}_{\mathrm{i}}$ & $\mathrm{D}_{1}$ & $\mathrm{D}_{2}$ & $\mathrm{D}_{\mathrm{x}}$ \\
\hline
\end{tabular}

Treatment 1

Feed Com. FM42 MG35

$\begin{array}{lllll}1 & 3.50 & 6.85 & 9.42 & 12.51^{*} \\ 4 & 7.50 & 4.78 & 4.36 & 5.74 \\ 6 & 6.00 & 2.28 & 7.07 & 2.77\end{array}$

Treatment 2

Feed

Com. MG35 FM42

$\begin{array}{lllll}2 & 3.28 & 3.57 & 6.35 & 3.50 \\ 3 & 0.92 & 6.07 & 4.71 & 3.57 \\ 5 & 8.21 & 2.43 & 5.14 & 9.55\end{array}$

